\title{
A ve B Kişilik Tiplerinin Boş Zaman Davranışlarının Kıyaslanması*
}

\author{
Ceren AYDIN, Çağıl Hale ÖZEL ${ }^{* *}$
}

A ve B Kişilik Tiplerinin Boş Zaman Davranışlarının Kıyaslanması

\section{Özet}

Bu çalışma, A ve B kişilik tiplerinin boş zaman davranışlarının kıyaslanmasını amaçlamaktadır. Çalışma kapsamında $A$ ve $B$ kişilik tiplerinin hangi güdülerle boş zaman aktivitelerine yöneldiği ve hangi boş zaman aktivitelerini tercih ettiği araştırımıştır. Araştırmaya konu olan veriler, 11 Mayıs-15 Haziran 2015 tarihleri arasında Eskişehir ilinin Odunpazarı ve Tepebaşı ilçelerinde yer alan boş zaman hizmeti sunan mekânlardan anket tekniği ile elde edilmiştir. Yapılan analizler sonucunda $A$ ve $B$ kişilik tiplerini boş zaman aktivelerine katılmaya güdüleyen altı faktör; sosyalleşme, kişisel gelişim ve başarma, rekabet, yenilenme ve rahatlama, kaçı̧̧ ve keşfetme olarak belirlenmiştir. Rekabet faktörünün kişilik tipine göre farklılaştığı, ayrıca A ve B kişilik tiplerinin katılmayı tercih ettiği boş zaman aktivitelerinin farklı olduğu ortaya çıkarılmıştır. Çalışmanın sonuçlarının; boş zaman endüstrisinde faaliyet gösteren işletmelere; pazarlama karması oluşturmada, ürettikleri mal ve hizmetlerin planlanmasında ve tanıtılmasında yol gösterici olması beklenmektedir.

Anahtar Kelimeler: Güdülenme, Boş Zaman Davranışları, A ve B Kişilik Tipleri, Eskişehir.
The Comparison of the Leisure Activities of Type A and B Personalities

Abstract

The present research aims to compare the leisure activities of $A$ and $B$ type personalities. In this regard, leisure motivations and activity choices of $A$ and $B$ type personalities were investigated in this study. Questionnaires were collected from places offering leisure services in Odunpazarı and Tepebaşı districts of Eskişehir, between May $11^{\text {th }}, 2015$ and June $15^{\text {th }}$, 2015. Factors, motivating the $A$ and $B$ type personalities to attend certain types of leisure activities were named as; Socialization, Personal Growth and Success, Competition, Renewal and Relaxation, Escaping and Discovery. Competition factor differed according to the personality type of the individual. Furthermore, it was determined that leisure activities that $A$ and $B$ personalities chose to attend were different.

Key Words: Motivation, Leisure Behavior, A and B Personality Types, Eskişehir.

\section{Giriş}

İnsanlar sanayi devrimiyle başlayan ve günden güne gelişen teknolojiyle birlikte daha fazla boş zaman elde etmeye başlamıştır. Bu gelişmenin bir sonucu olarak, kent nüfusunda artış, harcanabilir gelir artışı, eğitim seviyesindeki gelişmeler, çalışma hayatının kurallara bağlanması gibi olumlu ilerlemeler elde edilmiştir. Ancak, bu olumlu gelişmelerin yanında 21. yüzyılda yaşanan yoğun rekabet

\footnotetext{
*Bu makale, Ceren AYDIN'ın Anadolu Üniversitesi Sosyal Bilimler Enstitüsü Turizm İşletmeciliği Anabilm Dalı’nda yazıIan A ve B Kişilik Tiplerinin Boş Zaman Davranışlarının Kıyaslanması başlıkı yüksek lisans tezinden üretilmiştir.

${ }^{* *}$ Ceren AYDIN,Doktora Öğrencisi, Anadolu Üniversitesi, Sosyal Bilimler Enstitüsü,Turizm İşletmeciliği Anabilim Dalı, cerendiktas@anadolu.edu.tr; Çağıl Hale ÖzEL, Doç.Dr., Anadolu Üniversitesi , Turizm Fakültesi,Turizm İşletmeciliği Bölümü, chkayar@anadolu.edu.tr
} 


\section{Ceren AYDIN | Çağıl Hale ÖZEL}

ortamı, çevre sorunları, gün içinde yaşamın hızlı akışı, sorumlulukların artışı gibi unsurlar, bu çağın insanı üzerinde yoğun bir baskı ve stres yaratmaktadır. Bireyi, yaşadığı bu olumsuz etkilerden uzaklaştırmak ve bireyin yenilenmesini sağlamak amacıyla boş zaman endüstrisi önem kazanmıştır. Boş zamanlarında mümkün olduğunca en fazla yararı elde etmek isteyen boş zaman tüketicileri, herhangi bir boş zaman faaliyetini seçerken çeşitli faktörleri göz önünde bulundurur. Bu faktörlerden biri, zamandır. Çünkü zaman, tasarruf edilemeyen ve tekrar kullanılamayan bir olgudur. Diğer bir etken ise bireyin demografik özellikleridir. Kovacs (2007), bireyin cinsiyetine, eğitim ve gelir düzeyine göre tercih ettiği boş zaman aktivitelerinin farklılık gösterdiğini belirtmektedir. Yapılan çalışmalar (Plog, 2001; Barnett, 2006; Harden, 2008) incelendiğinde, boş zaman aktivite tercihini etkileyen bir diğer faktörün, bireyin kişilik özellikleri olduğu görülmektedir. Bu özellikler, kişinin katılacağı boş zaman aktivitelerinin belirlenmesine, kişinin zevklerinin oluşmasına ve aktiviteden alacağı hazza kadar birçok unsuru etkilemektedir.

Konuyla ilgili önceki çalışmalarda bireylerin, farklı demografik ve fiziksel özelliklerine göre hangi boş zaman aktivitelerine katıldığı ve bu bireyleri boş zaman aktivitelerine iten nedenlerin neler olduğu araştııımıştır. Ancak, bireyin kişilik özellikleriyle katıldı̆ı boş zaman aktiviteleri arasında ilişki kurulmasına yönelik araştırmalar kısıtı kalmıştır. Bu çalışma, Friedman ve Rosenman'ın 1974 yılında ileri sürdüğü A ve B Kişilik Modeli ile bireylerin boş zaman aktivitelerine katılım güdüleri ve katıldıkları boş zaman aktivite türleri arasındaki ilişkiyi ortaya koymayı amaçlamaktadır. Böylece, boş zaman endüstrisinde faaliyet gösteren boş zaman işletmeleri, pazarlama karmalarını oluştururken hangi kişilik tipinin, hangi güdülerle kendi ürünlerini tercih ettiğini anlayabilecektir. Bu endüstri içinde yer alan işletmeler, ürettikleri mal ve hizmetlerin planlanması ve tanıtılması aşamasında, hitap ettikleri kişilik tipine göre pazara daha uygun ürünler sunabilecektir.

\section{Kişilik Kuramları}

Kişiliğin nasıl oluştuğu, hangi faktörlerden etkilendiği, nasıl geliştiği, özelliklerinin neler olduğu, bireyin hangi durumlarda nasıl tepki verdiği gibi konular, kişilik kuramları kapsamında ele alınmaktadır. Alanyazın incelendiğinde kişilik kuramlarının altı genel başlık altında toplandığı söylenebilir. Kişilik kuramları, bu kuramların öne sürdüğü temel esaslar ve temsilcileri, Tablo 1'de gösterilmiştir.

Tablo 1. Kişilik Kuramları

\begin{tabular}{|c|c|c|}
\hline Kuram & Açıklama & Kuramın Temsilcileri \\
\hline $\begin{array}{l}\text { Psikanalitik } \\
\text { Kuram }\end{array}$ & $\begin{array}{l}\text { Bireylerin davranışlarındaki farklıığın } \\
\text { bilinçaltı sisteminden kaynakladığını } \\
\text { ileri sürer. }\end{array}$ & $\begin{array}{l}\text { Sigmund Freud, Cari Jung, Alfred } \\
\text { Adler, Erik Erikson, Karen Horney, } \\
\text { Harry Stack Sullivan, Erich Fromm }\end{array}$ \\
\hline $\begin{array}{l}\text { Ayırıcı Özellik } \\
\text { Kuramı }\end{array}$ & $\begin{array}{l}\text { Bireyin ayırıcı özelliklerini oluşturan } \\
\text { ve onu diğer bireylerden ayıran farklı } \\
\text { kişilik özelliklerinin olduğunu belirtir. }\end{array}$ & $\begin{array}{l}\text { Gordon Allport, Henry Murray, Ray- } \\
\text { mond Cattell }\end{array}$ \\
\hline
\end{tabular}




\begin{tabular}{|c|c|c|}
\hline $\begin{array}{l}\text { Biyolojik } \\
\text { Kuram }\end{array}$ & $\begin{array}{l}\text { Bireyler arasındaki kişilik farklılıkla- } \\
\text { rını kalıtsal özelliklerle ve fizyolojik } \\
\text { süreçlerle açıklar. }\end{array}$ & Hans Eyesenck \\
\hline $\begin{array}{l}\text { İnsancıl } \\
\text { Kuram }\end{array}$ & $\begin{array}{l}\text { Bireylerin, kendi eylemlerinden bü- } \\
\text { yük oranda sorumlu olduğunu varsa- } \\
\text { yarak, bireyin kendisi ve doğasıyla } \\
\text { uyum içinde olabilmek için bilinçli bir } \\
\text { şekilde davrandığını belirtir. }\end{array}$ & $\begin{array}{l}\text { Cari Rogers, Abraham Maslow, Mi- } \\
\text { haly Csikszentmihayli }\end{array}$ \\
\hline $\begin{array}{l}\text { Davranışsal } \\
\text { Ve } \\
\text { Sosyal Öğ- } \\
\text { renme }\end{array}$ & $\begin{array}{l}\text { Bireyin tutarlı davranış kalıplarının } \\
\text { koşullanma ve beklentiler sonu- } \\
\text { cunda oluştuğunu varsayar. }\end{array}$ & $\begin{array}{l}\text { John B. Watson, B.F Skinner, Julian } \\
\text { B. Rotter, Albert Bandura. }\end{array}$ \\
\hline $\begin{array}{l}\text { Bilişsel } \\
\text { Kuram }\end{array}$ & $\begin{array}{l}\text { Kişilik özelliklerinin bireyden bireye } \\
\text { farklılık göstermesinin bireylerin bil- } \\
\text { giyi işleme yöntemlerindeki farklılık- } \\
\text { lardan kaynakladığını savunur. }\end{array}$ & $\begin{array}{l}\text { Kurt Lewin, George Kelly, Albert El- } \\
\text { lis }\end{array}$ \\
\hline
\end{tabular}

Kaynak: Burger, 2006, ss. 25-641'den derlenmiştir.

Bu çalışmada Ayırıcı Özellik Kuramı́ndan yararlanıımıştır. Ayırıcı Özellik Kuramı, bireyin belli bir özelliği ne ölçüde taşıdığı ile ilgilenir. Bu kuram, bireyin sahip olduğu kişilik özelliklerinin değişmez olduğunu ve bu özelliklerin kararlılık gösterdiğini kabul eder (Inanç ve Yerlikaya, 2010, s. 251). Bireyin kişilik özelliklerinin değişmez olması, bireyin davranışlarının zaman içinde farklılık göstermemesi anlamına gelir. Örneğin, sosyal yönü gelişmiş bir bireyin, diğer bireylerle vakit geçirmekten hoşlanma özelliği, zaman içinde değişmez. Kişilik özelliklerinin kararlılık göstermesi ise şöyle bir örnekle açıklanabilir: Eğer birey saldırgan özellikteyse bu saldırganlık özelliği, futbol oynarken veya sosyal hayatında bir tartışma yaşadığında da ortaya çıkar. Ayıııcı Özellik Kuramı’nı savunanlar, bireyin davranışlarının altında yatan nedenle ilgilenmezler, bireyin sahip olduğu kişiliği tanımlamaya ve davranışı tahmin etmeye odaklanırlar. Dolayısıyla Ayırıcı Özellik Yaklaşımı, bireylerin sahip olduğu kişilik özellikleri arasında karşılaştırma yapma olanağı sağlar (Burger, 2006, ss. 233-237).

Kişilik kuramlarından yola çıkılarak bireyin kişilik özelliklerinin iç faktörler ve çevre faktörleri sonucunda şekillendiği görülmektedir. Bireylerarası farklıık gösteren bu faktörler, bireylerin yetenekleri, duyguları, algıları, tercihleri, eğilimleri ve çevrelerinde gelişen olaylara karşı olan tutumlarında da farklılık yaratmaktadır. Bu nedenle araştırmacılar, bireyin sahip olduğu kişilik özelliklerini ortaya koyarak bu özelliklerin bireyin yaşamını nasıl şekillendirdiğini belirleyebilmek için çeşitli kişilik modelleri oluşturmuşlardır.

Ayırıc Özellik Kuramı kapsamında ele alınan kişilik modellerinden biri, Myers ve Briggs Kişilik Modeli'dir. Bu modelde kişilik tipleri; içe dönük, dışadönük, duyusal, sezgisel, düşünen, hisseden, yargılayıcı ve algılayıcı olarak belirlenmiştir (Myers ve Myers, 1980, ss. 28-31). Bu sekiz kişilik özelliğini 


\section{Ceren AYDIN | Çağıll Hale ÖZEL}

birbiriyle eşleştiren model, toplam 16 kişilik tipi ortaya çıkarmaktadır. Kişiliğin temel boyutlarını belirlemeye yönelik başka bir çalışma da McCrea ve Costa tarafından yapılan Beş Faktör Kişilik Modeli'dir. Beş faktör kişilik özellikleri; nevrotiklik, dışadönüklük, açıklık, uyumluluk ve öz disiplindir (McCrea ve Costa, 2003 s. 34). Dışadönük bireyler, hareketli ve enerjiktir. Bu bireyler, sporla uğraşmaktan zevk alırlar. Bir etkinlikten başka bir etkinliğe hızla geçiş yaparlar. Aynı zamanda dışa dönük bireyler, değişik ilgi alanlarını takip etme ve deneme eğilimindedirler. İçedönük bireyler, fiziksel açıdan hareketsizdir. Hareketli aktivitelerden çok, sakin ve dinlendirici tatilleri tercih ederler (Eysenck ve Wilson, 1995, s. 55). Ayırıcı Özellik Yaklaşımı içinde ele alınan bir diğer kişilik modeli de A ve B kişilik tipleridir (Burger, 2006, s. 299). Kişilik özelliklerini iki gruba ayıran bu analiz, Friedman ve Rosenman (1974) tarafından ortaya çıkarılmıştır.

\subsection{A ve B Tipi Kişilik Modeli}

Friedman ve Rosenman'a göre A tipi kişilik yapısına sahip bireyler; stresli, sabırsız, konuşma sırasında karşı tarafın sözünü kesen, hızlı hareket eden, ısrarcı, mental ve fiziksel fonksiyonları hızlı olan, rekabetten hoşlanan ve işlerini çok fazla önemseyen, idealist, mücadele yapısı yüksek kişilerdir (Friedman ve Rosenman, 1974, s. 100). Bu bireyler, zorlukların üstesinden gelmek için güdülenirler. Tanınırlıktan ve kazanmaktan hoşlanırlar (Burger, 2006, s. 300). Bunun yanında A tipi kişilik, aynı anda birden fazla konu hakkında düşünen, rahatlamak için birkaç gün veya birkaç saat hiçbir iş yapmadan durduğunda kendini suçlu hisseden, iyi olduğunu düşündüğü konularda başkalarından daha hızlı ve başarılı olmaktan haz duyan ve belirli karakteristik vücut hareketleri ve tikleri olan kişilik türüdür. B tipi kişilik özelliği baskın olan bireyler ise rahat, esnek, sabırlı, başarılarını başkalarıyla paylaşma gereksinimi hissetmeyen, üstünlük taslamayan, rahatlamak için kendine vakit ayırdığında suçluluk duygusu hissetmeyen, sosyal yaşamı seven, sağlığına düşkün, sakin, sorumluluk duygusu düşük olan, stresten uzak ve oyunlarda kazanmayı değil, eğlenmeyi amaçlayan kişilik tipidir (Friedman ve Rosenman, 1974, s. 103).

Kişilik modellerinden yola çıkarak bireylerin sahip olduğu kişilik özelliklerinin, iş hayatında ve sosyal hayatta ön plana çıktığı görülmektedir. Bu çalışmada ise kişilik özelliklerinin, bireyin boş zaman davranışlarını nasıl etkilediğini ortaya koyabilmek için iki farklı kişilik tipini karşılaştırmaya olanak tanıyan A ve B tipi Kişilik Modeli'nden yararlanılmaktadır. Çalışmada bahsi geçen diğer kişilik modelleri (Myers-Briggs' in Kişilik Modeli, Beş Faktör Kişilik Modeli), bireyin sahip olduğu baskın kişilik özelliklerini ortaya çıkarmakta ve bireylerin boş zaman davranışlarını kıyaslamaya olanak tanımamaktadır. Ancak, A ve B Tipi Kişilik Modeli, farklı bireylerin hangi tip kişilik özelliğine sahip olduğunu ortaya çıkartarak, bireylerin boş zaman aktivite tercihlerinin karşılaştııılmasına fırsat vermektedir. Bu çalışmada, kişilik özellikleri ile boş zaman davranışı arasında karşılaştırmalar yapılacak olması nedeniyle A ve $B$ Tipi Kişilik Modeli'nin kullanılması tercih edilmiştir.

\section{3. ilgili Çalışmalar}

Kişisel farklılıklar, boş zamanları dolduran aktivite türlerini etkileyebilmektedir. Mannell ve Kleiber'e (1997) göre, bireylerin boş zamanlarında kendini ifade etmede karşılaştığı kısıtlamalar, günün 
diğer zamanlarında hissettiği kısıtlamalara kıyasla daha düşüktür. Bu nedenle bireyler, kendi benliklerini boş zamanlarında daha iyi ifade edebilirler. Boş zaman aktivitelerinde, kendileri olmakta bir sakınca görmezler ve benliklerini ortaya koyarlar. Benzer şekilde Larsen, Diener ve Emmons (1985), yaptıkları araştırmada bireylerin kişiliklerinin iş ortamlarından çok boş zaman aktivitelerinde yaptıkları seçimlerde etkili olduğunu belirtmiştir. Yapılan çalışmalar (Plog, 2001; Barnett, 2006; Harden, 2008) incelendiğinde, bireyin kişilik özelliklerinin, bireyin katıldığı aktivite türlerini etkilediği görülmektedir.

A ve B tipi kişiliği ortaya çıkaran Rosenman ve Friedman (1974), B tipi kişilik özelliği baskın olan bireylerin, yarışma ve rekabet içeren boş zaman aktivitelerini tercih etmediğini, rekreatif aktivitelere daha çok rahatlamak için katıldıklarını belirtmişlerdir. Jenkins (1975) ise A tipi kişilik özelliğine sahip olan bireylerin, B tipi kişilik özelliğine sahip bireylere kıyasla kültürel aktiviteleri daha az tercih ettiğini belirtmiştir.

A ve B kişilik tipleri ile boş zaman aktiviteleri üzerine çalışma yapan Becker ve Byrne (1984), A tipi kişilik özellikleri baskın olan bireylerin, boş zaman aktivitelerine ve başka insanlarla vakit geçirmeye daha az vakit ayırdığını ortaya koymuşlardır. Bu çalışmaya benzer olarak Burke ve Deszca (1984), A tipi kişiliğin kendisi için gerekli olan dinlenme ve rahatlama faaliyetlerine zaman ayırmayı tercih etmediğini, boş zaman aktivitelerine vakit ayırmaktansa çalışmayı tercih ettiğini belirtmiş̧ir. Iso-Ahola ve Weissinger (1985), A tipi kişilik özelliğine sahip bireylerin, rekabet içerikli spor aktivitelerine, fitness aktivitelerine ve açık alan aktivitelerine katıldıklarını, B tipi kişiliklerin ise spor aktivitelerine aktif olarak katılmaktan çok izleyici olarak katıldıklarını belirtmiştir. Tang, 1986 yılında yaptığı çalışmasında, Becker ve Byrne'nın (1984) ulaştığı sonuçların aksine, A kişilik yapısına sahip bireylerin iş için ayırdığı zamanla, boş zaman aktivitelerine ayırdığı zamanın eşit olduğunu saptamıştır. Tang (1986), A tipi kişilik yapısına sahip bireylerin, çalışma zamanlarında ve boş zamanlarında yarışmacı özelliklerini ön plana çıkardıklarını ve bu kişilik özelliğine sahip bireylerin, iş yaşantılarıyla boş zaman aktivitelerindeki amaçlarının farklılık göstermediğini belirtmiştir. Ancak, B tipi kişilik özelliğine sahip bireylerin boş zaman aktivitelerini çalışmaya tercih ettikleri tespit edilmiştir. Tang (1988), Çin'de üniversite öğrencileri üzerinde yaptığı çalışmasında, A tipi öğrencilerin canlı konserlere, müzik içeren şovlara ve gösterilere $B$ tipi öğrencilerden daha çok katıldıkları sonucuna ulaşmıştır. A tipi kişiliğin, dinlenmek ve rahatlamak için oturmaktansa keşfetmekten ve hareket etmekten hoşlandığını belirtmiştir. Bu nedenle, A tipi kişilik özelliğine sahip bireylerin, tiyatro veya film izlemek gibi pasif aktiviteleri tercih etmediğini öne sürmüştür.

Yapılan önceki çalışmalarda A ve B tipi kişilik özelliklerine sahip bireylerin boş zaman davranışlarındaki farklılıklara değinilmiştir. Bu farklııklardan yola çıkılarak, A ve B tipi kişilik özelliklerine sahip bireylerin boş zaman davranışları, sınırlı sayıdaki aktivite üzerinden değerlendirilmiştir. Ancak, yapılan çalışmalarda A ve B tipi kişilik özelliklerine sahip bireylerin boş zaman faaliyetlerine katılım güdülerine değinilmemiştir. Bu çalışmanın, A ve B kişilik tiplerini boş zaman aktivitelerine yönelten güdülerin ortaya çıkarıımasıyla alanyazına katkı sağlaması beklenmektedir. Çalışmanın uygulamaya dönük katkısı ise boş zaman endüstrisinde ürün sunan işletmelerin, ürünlerini oluştururken hangi kişilik 
Ceren AYDIN | Çağıl Hale ÖZEL

tipinin, hangi güdülerle kendi ürünlerini tercih edebileceğini anlamalarını sağlaması olacaktır. Bu endüstri içinde yer alan işletmeler, ürünlerinin planlanmasında ve tanıtılmasında, farklı kişilik tiplerinin istek ve gereksinimlerine göre pazara uygun ürünler sunabilecektir.

\section{Yöntem}

\subsection{Araştırmanın Amacı ve Önemi}

Bu çalışmada, A tipi ve B tipi kişiliğe sahip olan bireylerin boş zaman aktivitelerine katılım güdüleri ve katıldıkları boş zaman aktivite türleri arasında anlamlı farklılıklar olup olmadığının incelenmesi amaçlanmaktadır. Diğer bir ifade ile A ve B kişilik tiplerinin, boş zaman aktivite tercihlerini belirlemek ve bu kişilik tiplerinin boş zaman aktivite tercihi üzerinde anlamlı bir farklılaşmaya yol açıp açmadığını ortaya koymaktır. Ayrıca, A ve B kişilik tiplerinin boş zaman aktivitelerine katılım amaçları arasındaki olası anlamlı farklılaşma ortaya çıkarılmaya çalışılmıştır. Araştırma kapsamında yanıtı aranan sorular, aşağıdaki gibi sıralanabilir;

- $\quad$ A ve B tipi kişiliğe sahip olan bireylerin katıldıkları aktiviteler, kişilik tipine göre farklılık göstermekte midir?

- A ve B tipi kişiliğe sahip olan bireylerin boş zaman aktivitelerine katılım güdüleri, kişilik tipine göre farklılık göstermekte midir?

- $\quad$ A ve $B$ tipi kişiliğe sahip olan bireylerin boş zaman aktivitelerine katılım amaçları, kişilik tipine göre farklılık göstermekte midir?

Çalışmanın bulgularından hareketle boş zaman hizmeti sunan işletmeler, A ve B kişilik tipinin boş zaman tercihlerinin nasıl farklılaştı̆̆ını anlayabilecek ve her bir kişilik tipine uygun pazarlama karmaları oluşturabilecektir. İşletmeler tarafından müşterilerinin kişilik özelliklerinin ve hangi güdülerle boş zaman aktivitelerine yöneldiklerinin bilinmesi, işletmelerin müşteri beklentilerini daha iyi karşılayabilmesi ve müşteri tatmini sağlaması noktasında önem taşımaktadır. Boş zaman endüstrisine ürün sunan işletmeler, müşterilerine daha iyi hitap edebilmek için, ürettikleri mal ve hizmetleri tam olarak müşterinin istediği biçıimde sunmalıdır. Bu nedenle, farklı kişilik tiplerinin hangi güdülerle satın alma davranışı içinde bulunacağının bilinmesi, müşterilerle kurulan ilişkilerin geliştirilmesinde önemli bir role sahiptir.

\subsection{Evren ve Örneklem}

Araştırmanın evrenini, Eskişehir'de yaşayan ve boş zaman aktivitelerine katılan Türk vatandaşları oluşturmaktadır. Araştırmada çok aşamalı örneklem yöntemi kullanılımışır. Araştırmanın örnekleme yönteminin ilk aşamasında, kota örnekleme yöntemine başvurulmuştur. Bu aşamada, TUiK'in 2014 yllı nüfus verilerine göre Eskişehir nüfusunun $(812,230) \% 86,20$ 'sini oluşturan Odunpazarı $(376,650)$ ve Tepebaşı $(323,631)$ ilçelerindeki nüfus yoğunluğu dikkate alınmıştır. Bu kapsamda elde edilen verilerin \%54'ü Odunpazarı ilçesinden, $\% 46$ 'sı ise Tepebaşı ilçesinden elde edilmiştir. Örneklemin bu iki ilçeden seçilmesinin nedeni, Eskişehir nüfusunun oransal olarak büyük bir kısmının bu 
iki ilçede ikamet ediyor olmasıdır. Ayrıca Odunpazarı ve Tepebaşı ilçelerinin nüfusunun, toplam nüfus oranı içindeki payının yüksek olması nedeniyle, nüfusun gereksinim duyduğu boş zaman aktivite türlerinin arzı, bu iki ilçede yoğunlaşmıştır. Araştırmanın ikinci aşamasında, tesadüfi olmayan örnekleme yöntemlerinden yargısal örnekleme yöntemi tercih edilmiştir.

Tablo 2'de boş zaman aktivite grupları, ayrıntılı olarak gösterilmektedir. Bu aktivite gruplarının her biri için mekânlar belirlenmiştir. Sözgelimi, sosyal içeriği yüksek olan aktivite alanı olarak kafeler, kültürel ve sanatsal aktivite alanı olarak tiyatro salonları, sportif uğraşlarda aktif olunan aktiviteler için fitness salonları, seyirci olarak katılınan sportif aktiviteler için basketbol ve futbol maçları, gündelik açık alan aktiviteleri için yürüyüş alanları ve gecelik konaklama içeren aktiviteler için ise oteller yargısal örneklem yöntemi ile belirlenmiştir. Örneklemin son aşamasında ise kolayda örnekleme yönteminden yararlanılmıştır. Bu mekânlarda bulunan bireyler, araştırmacılar tarafından kolayda örneklem yöntemiyle seçilmiştir.

Tablo 2. Boş Zaman Aktivite Grupları ve Aktivite Türleri

\begin{tabular}{|c|c|}
\hline Aktivite Grupları & Aktivite Türleri \\
\hline Evde yapılan aktiviteler & $\begin{array}{l}\text { İnternete bağlanmak, TV izlemek, kitap okumak, bahçe işleri } \\
\text { ile uğraşmak, yemek yapmak, müzik dinlemek, konsol oyun- } \\
\text { ları oynamak. }\end{array}$ \\
\hline $\begin{array}{l}\text { Sosyal içeriği yüksek olan ak- } \\
\text { tiviteler }\end{array}$ & $\begin{array}{l}\text { Kafelerde oturmak, partilere gitmek, arkadaş-akraba ziyaret- } \\
\text { lerine gitmek, vakıf-dernek faaliyetlerine katılmak. }\end{array}$ \\
\hline $\begin{array}{l}\text { Kültürel ve sanatsal aktivite- } \\
\text { ler }\end{array}$ & $\begin{array}{l}\text { Tiyatroya, konsere, müzelere, festivallere, sergiye, festival- } \\
\text { lere gitmek, hobi kurslarına katılmak. }\end{array}$ \\
\hline $\begin{array}{l}\text { Sportif uğraşlarda aktif olu- } \\
\text { nan aktiviteler }\end{array}$ & $\begin{array}{l}\text { Futbol, basketbol, yüzme, dağcılık gibi spor aktivitelerine ve } \\
\text { fitness, pilates gibi egzersiz aktivitelerine katılmak. }\end{array}$ \\
\hline $\begin{array}{l}\text { Sportif aktivitelere seyirci } \\
\text { olarak katılınan aktiviteler }\end{array}$ & $\begin{array}{l}\text { Stadyumlarda futbol, salonlarda basketbol ve voleybol maç- } \\
\text { larını izlemek. }\end{array}$ \\
\hline Gündelik açık alan aktiviteleri & $\begin{array}{l}\text { Pikniğe gitmek, yürüyüş yapmak, avcılık-balıkçılık yapmak, } \\
\text { fotoğraf çekmek. }\end{array}$ \\
\hline $\begin{array}{l}\text { Gecelik konaklama içeren tu- } \\
\text { rizm aktiviteleri }\end{array}$ & Şehir dışına yapılan turlara katılmak. \\
\hline
\end{tabular}

Kaynak: Baud-Bovy ve Lawson (1998, s. 1) ve Karaküçük ve Gürbüz’den (2007, s. 35) uyarlanmıştır.

\subsection{Soru Formunun Oluşturulması}

Soru formu, demografik bilgilerin elde edildiği, A ve B kişilik tipinin ölçüldüğü, boş zaman aktivite türlerinin seçildiği ve boş zaman aktivitelerine katılımı sağlayan amaçların belirlendiği dört bölümden oluşmaktadır. Soru formunun ilk bölümünde katılımcıların yaş, cinsiyet, meslek ve eğitim durumuna ilişkin bilgilerin derlendiği demografik sorular yer almaktadır. İkinci bölümde katıımcıların kişilik özelliklerini belirlemek amacıyla, yedi ifadeden oluşan A ve B kişilik tipi ölçeğinden yararlanılmıştır. Friedman ve Rosenman tarafından geliştirilen bu ölçek, Aktaş ve Arıkan tarafından 1988 yılında Türkçeye uyarlanmıştır (Akt; Aktaş, 2001, s. 34). Bu ölçek, yedi ifadeden oluşan 8'li Likert tipi bir ölçektir. Yanıtlayıcıların katıldıkları boş zaman aktivitelerinin türlerini belirlemeye yönelik olarak oluşturulan 


\section{Ceren AYDIN | Çağıll Hale ÖZEL}

üçüncü bölüm ise Baud-Bovy ve Lawson'ın 1998 yılında yaptığı boş zaman aktivite sınıflandırmasından uyarlanmıştır (Tablo 2). Bu bölümde katılımcıların en çok haz aldıkları aktivite türünü seçmeleri istenmiştir. Ayrıca katıımcılara, boş zaman aktivitelerine katılımlarını sağlayan temel amacı belirlemeye yönelik tek bir soru sorulmuştur.

Katılımcıların boş zaman aktivitelerine katılım güdülerine yönelik ifadeler soru formunun dördüncü bölümünü oluşturmaktadır. Bu bölümdeki ifadeler, alanyazından yararlanılarak belirlenmiştir. Tablo 3'te görüldüğü gibi beş farklı çalışmada bahsi geçen toplam 34 ifadeden yararlanılmıştır. Soru formunun bu bölümündeki sorular, 5 'li Likert tipi ifadelerle değerlendirilmiştir.

Tablo 3. Soru Formunda Kullanılan Ifadelerin Derlendiği Çalışmalar

Kişilerin Boş Zaman Aktivitelerine Katı-

Iım Güdülerini Belirlemeye Yönelik ifa- Yer Aldığı Çalışma ve Yılı

deler

Stresimi azalttığı için katılırım.

Morris ve Rogers (2004), Rogers ve Morris (2003), Dillard ve Bates (2011), Manfredo, Driver ve Tarrant (1996)

Yenilenmek için katılırım.

Dillard ve Bates (2011)

Yeni insanlarla tanışma fırsatı bulduğum için katılırım.

Manfredo, Driver ve Tarrant (1996), Dillard ve Ba-

Rahatlamak için katılırım.

tes (2011), Rogers ve Morris (2003)

Morris ve Rogers (2004), Rogers ve Morris (2003),

Dillard ve Bates (2011), Pelletier, Vallerand, Blais

ve Briere (1989)

Hayatıma yeni bir bakış açısı kazandır- Manfredo, Driver ve Tarrant (1996)

dığı için katılırım.

Arkadaşlarımın isteği üzerine katılııım. Morris ve Rogers (2004), Rogers ve Morris (2003)

Kendimi geliştirme fırsatı verdiği için ka- Manfredo, Driver ve Tarrant (1996), Pelletier, Valtılırım. lerand, Blais ve Briere (1989), Dillard ve Bates (2011), Morris ve Rogers (2004), Rogers ve Morris (2003)

Yapılması gereken işleri düşünmekten kurtulmak için katılırım.

Manfredo, Driver ve Tarrant (1996), Pelletier, Vallerand, Blais ve Briere (1989), Dillard ve Bates (2011)

Kendime olan güvenimi arttırdığı için Manfredo, Driver ve Tarrant (1996), Pelletier, Valkatılırım. lerand, Blais ve Briere (1989), Dillard ve Bates (2011)

Arkadaşlarımla vakit geçirebilme ola- Morris ve Rogers (2004), Rogers ve Morris (2003), nağı bulabildiğim için katılırım. Dillard ve Bates (2011), Manfredo, Driver ve Tarrant (1996) 
Baskılardan uzaklaşmak için katılırım. Morris ve Rogers (2004), Rogers ve Morris (2003), Dillard ve Bates (2011), Manfredo, Driver ve Tarrant (1996)

Sosyal statü kazanmama yardımcı olduğu için katılırım.

Diğer insanları gözlemlemek için katılırım.

Yeni beceriler edinmek için katılırım.

Kendimi meşgul etmek için katılırım.

Ailemle daha yakın ilişkiler kurabilmek için katılırım.

Zihnimi rahatlatmak için katılırım.

Başkaları tarafından takdir edilmek için katılırım.

Diğer insanlarla yarışmak için katılırım.

Yapabildiklerimi diğer insanlara gösterebilmek için katılırım.

Eğlenmek için katılırım.

Mutlu olmak için katılırım.

Sınırlarımı zorlamak için katııırım.

Hayatımın diğer alanlarında daha başarılı olmamı sağladığı için katııırım.

Kendimi dinlemek (kafamı dinlemek) için katılırım.

Yeteneklerimi geliştirmek için katılırım.

Benimle aynı ilgi alanına sahip olan insanlarla bir araya gelebilmek için katılırım.

Kendimi özgür hissetmek için katılırım.

Diğer insanlara kendimi dinamik (hareketli) gösterme fırsatı verdiği için katılırım.
Rogers ve Morris (2003)

Manfredo, Driver ve Tarrant (1996)

Morris ve Rogers (2004), Rogers ve Morris (2003), Manfredo, Driver ve Tarrant (1996)

Pelletier, Vallerand, Blais ve Briere (1989)

Dillard ve Bates (2011)

Manfredo, Driver ve Tarrant (1996)

Manfredo, Driver ve Tarrant (1996)

Rogers ve Morris (2003)

Pelletier, Vallerand, Blais ve Briere (1989)

Morris ve Rogers (2004), Rogers ve Morris (2003), Dillard ve Bates (2011)

Manfredo, Driver ve Tarrant (1996), Rogers ve Morris (2003)

Morris ve Rogers (2004), Rogers ve Morris (2003), Pelletier, Vallerand, Blais ve Briere (1989)

Morris ve Rogers (2004), Rogers ve Morris (2003), Pelletier, Vallerand, Blais ve Briere (1989)

Manfredo, Driver ve Tarrant (1996), Pelletier, Vallerand, Blais ve Briere (1989)

Rogers ve Morris (2003)

Manfredo, Driver ve Tarrant (1996)

Morris ve Rogers (2004), Rogers ve Morris (2003), Manfredo, Driver ve Tarrant (1996)

Manfredo, Driver ve Tarrant (1996)

Pelletier, Vallerand, Blais ve Briere (1989), Manfredo, Driver ve Tarrant (1996)

Pelletier, Vallerand, Blais ve Briere (1989) 
Ceren AYDIN | Çağıl Hale ÖZEL

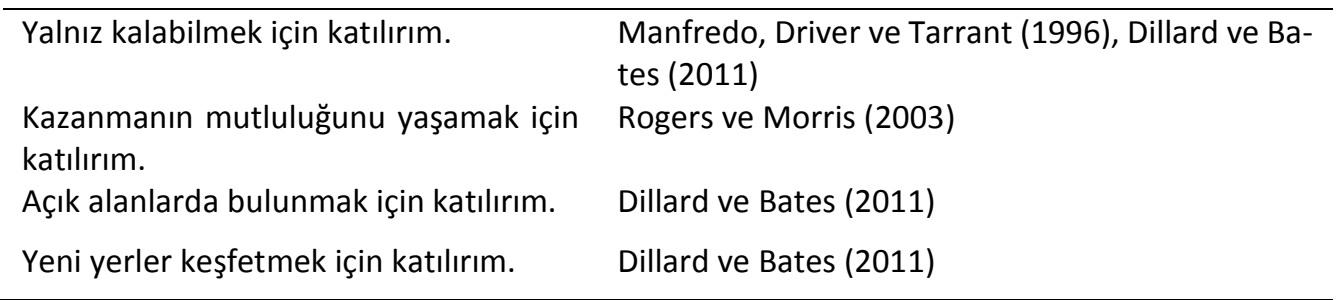

Soru formunun yüzey ve kapsam geçerliliği, eş zamanlı olarak uzmanlar tarafından değerlendirilmiştir. Araştırmacılar, bu aşamada boş zaman ve rekreasyon, pazarlama ve yönetim bilimleri alanında çalışan 21 uzmanın görüşlerine başvurmuştur. Soru formunda yer alan ifadelerin içsel tutarlıIığının sağlanması amacıyla boş zaman aktivitelerinin gerçekleştiği mekânlardan elde edilen bir örneklem grubu ( $n=72$ ) üzerinde pilot uygulama gerçekleştirilmiştir. Pilot çalışmanın güvenilirlik katsayısı (Cronbach Alpha) 0,929 olarak hesaplanmıştır.

\section{Veri Toplama Süreci}

Veriler, 11 Mayıs-15 Haziran 2015 tarihleri arasında araştırmacılar tarafından toplanmıştır. Araştırma kapsamında soru formunun eksiksiz veya yanlış doldurulmasının engellenmesi amacıyla katılımcılarla yüz yüze görüşülmüştür. Bu süreç sonunda araştırmacılar, toplam 417 soru formu toplamıştır. Bu soru formlarının 400'ü, kullanılabilir olarak araştırmaya dâhil edilmiştir. Araştırmaya dâhil edilen soru formlarının 74'ü kafelerden, 80'i tiyatro salonlarından, 66'sı fitness salonlarından, 89'u basketbol ve futbol maçlarından, $48^{\prime}$ i yürüyüş alanlarından ve $43^{\prime}$ ü otellerden toplanmıştır. Eksik ve hatalı doldurulmuş olan 17 adet soru formu ise araştırmaya dâhil edilmemiştir. Evrenin bütününe ulaşılamayan ve evren büyüklüğünün yüz milyon kişi olduğu durumlarda yüzde 95 güvenilirlik düzeyi için 384 örneklem sayısının yeterli olabileceği (Sekaran, 1992, s. 253; Saruhan ve Özdemirci, 2011, s. 144; Kozak, 2014, s. 113) ifade edilmektedir. Bu nedenle, kullanılabilir durumda olan 400 anket yeterli bulunmuştur.

\section{Bulgular}

Analiz aşamasında parametrik ya da parametrik olmayan analizlerden hangisinin kullanılacağının belirlenmesi için öncelikle verilerin normal dağılıp dağılmadığı incelenmiştir. Verilerin normal dağlıma uygunluğunu test etmek için ilk olarak, veri setindeki ifadelerin aritmetik ortalama, ortanca ve mod istatistiklerine bakılmış, bu değerlerin birbirine yakın olduğu görülmüştür. Yüzde 95 güven aralığında basıklık ve çarpıklık değerlerinin +2 ile -2 arasında olması, verilerin normal dağılıma yakın olduğunu göstermektedir (George ve Mallery, 2003, s. 97; Alpar, 2014, s. 152). Bu kapsamda çalışmada elde edilen verilerin basıklık ve çarpıklık değerlerine bakıldığında Likert tipi ifadelerin basıklık ve çarpıklık değerlerinin +2 ile -2 arasında olduğu görülmüştür. Parametrik hipotez testlerinin bir diğer varsayımı, verilerin ölçüm düzeyinin en az aralıklı ya da oransal olmasıdır (Kalaycı, 2014, s. 73). Aralıklı ölçek kapsamında değerlendirilen Likert ölçeğinden ise katılımcıların boş zaman aktivitelerine 
katılım güdülerini ölçmek için yararlanılmıştır. Likert tipi ölçek, ölçüm aralıklarının eşit olduğu varsayımından yola çıkılarak aralıklı ölçek olarak kabul edilmektedir (Powers ve Xie, 2000, s. 203; Nardi, 2006 , s. 54). Parametrik hipotez testlerinin varsayımlarına yönelik değerlendirmeler yapıldıktan sonra verilerin parametrik testlere uygun olduğuna karar verilmiştir.

\subsection{Açıklayıcı Faktör Analizine Yönelik Bulgular}

Çalışma kapsamında faktör analizi uygulanmadan önce verilerin faktör analizi için gerekli olan koşulları taşıyıp taşımadığı kontrol edilmiştir. Bu kapsamda araştırmanın örnekleminin yeterliliğini ölçmek için Kaiser-Meyer-Olkin (KMO) ve Bartlett Küresellik Testi (Bartlett's Test of Sphericity) testlerinden yararlanılmıştır. KMO değerinin $(0,877)$ ve Bartlett testinin $(9218,79)$ sonuçları incelenerek testlerin anlamlı sonuç verdiği $(0,000<0,05)$ tespit edilmiştir. Faktör analizi uygulanabilirliğinin diğer bir koşulu olarak, örneklem yeterlilik değerleri (Measure of Sampling Adequacy -MSA) çapraz ilişki matrisinde (Anti-image Correlation) 0,50'nin üzerinde olmalıdır (Durmuş, Yurtkoru ve Çinko, 2013, s. 81). Bu kapsamda çapraz ilişki katsayıları incelenmiş ve 0,50'nin altında hiçbir ifadenin olmadığı görülmüştür.

Faktör sayısının belirlenmesinde özdeğerlere göre boyut belirleme yöntemi kullanılmıştır. Bu yönteme göre özdeğeri 1'den büyük olan faktörler analize dâhil edilmelidir (Altunışık, Coşkun, Bayraktaroğlu ve Yıldıım, 2007, s. 232). Çalışmada kullanılan veri derleme aracı üzerinde faktör analizi uygulanmasında dik döndürme yöntemlerinden biri olan "Varimax" yöntemi tercih edilmiştir. Faktör analizi aşamasında, faktör yükü değerinin en az 0,40 olmasına (Kozak, 2014, s. 150) dikkat edilmiştir.

Tablo 4. Boş Zaman Aktivelerine Katılım Güdülerini Oluşturan Faktörler

\begin{tabular}{|c|c|c|c|c|c|}
\hline Faktör adı & 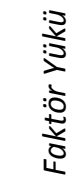 & $\begin{array}{l}0 \\
\frac{\delta}{0} \\
\frac{0}{0} \\
0\end{array}$ & 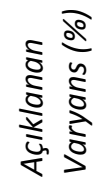 & $\begin{array}{l}\bar{d} \\
\text { oิ } \\
\frac{0}{N} \\
: 0\end{array}$ & 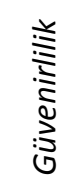 \\
\hline Sosyalleşme & & 3,68 & 17,78 & 9,28 & ,945 \\
\hline $\begin{array}{l}\text { Yeni insanlarla tanışma fırsatı bulduğum için ka- } \\
\text { tılırım. }\end{array}$ & ,907 & & & & \\
\hline $\begin{array}{l}\text { Benimle aynı ilgi alanına sahip olan insanlarla bir } \\
\text { araya gelebilmek için katılırım. }\end{array}$ & 903 & & & & \\
\hline Arkadaşlarımın isteği üzerine katılırım. & ,890 & & & & \\
\hline $\begin{array}{l}\text { Arkadaşlarımla vakit geçirebilme olanağı bulabil- } \\
\text { diğim için katılırım. }\end{array}$ & ,881 & & & & \\
\hline $\begin{array}{l}\text { Ailemle daha yakın ilişkiler kurabilmek için katılı- } \\
\text { rım. }\end{array}$ & ,830 & & & & \\
\hline Kendimi özgür hissetmek için katılırım. & ,755 & & & & \\
\hline Eğlenmek için katılırım. & ,713 & & & & \\
\hline Mutlu olmak için katılırım. & ,624 & & & & \\
\hline
\end{tabular}


Ceren AYDIN | Çağıl Hale ÖZEL

\begin{tabular}{|c|c|c|c|c|c|}
\hline Kişisel Gelişim ve Başarma & & 3,49 & 11,43 & 4,52 & 840 \\
\hline Yeni beceriler edinmek için katılırım. & ,743 & & & & \\
\hline $\begin{array}{l}\text { Hayatımın diğer alanlarında daha başarılı ol- } \\
\text { mamı sağladığı için katılırım. }\end{array}$ & ,719 & & & & \\
\hline Kendime olan güvenimi arttırdığı için katılırım. & 681 & & & & \\
\hline $\begin{array}{l}\text { Hayatıma yeni bir bakış açısı kazandırdığı için ka- } \\
\text { tılırım. }\end{array}$ & ,613 & & & & \\
\hline $\begin{array}{l}\text { Sosyal statü kazanmama yardımcı olduğu için ka- } \\
\text { tılırım. }\end{array}$ & 600 & & & & \\
\hline Kendimi geliştirme fırsatı verdiği için katılırım. & ,583 & & & & \\
\hline Sınırlarımı zorlamak için katılırım. & ,531 & & & & \\
\hline Yeteneklerimi geliştirmek için katılırım. & ,506 & & & & \\
\hline Rekabet Etme & & 2,65 & 10,41 & 2,92 & 841 \\
\hline Diğer insanlarla yarışmak için katılııım. & ,892 & & & & \\
\hline Diğer insanları gözlemlemek için katılırım. & ,830 & & & & \\
\hline $\begin{array}{l}\text { Yapabildiklerimi diğer insanlara gösterebilmek } \\
\text { için katılırım. }\end{array}$ & ,719 & & & & \\
\hline Başkaları tarafından takdir edilmek için katılırım. & 715 & & & & \\
\hline $\begin{array}{l}\text { Diğer insanlara kendimi dinamik (hareketli) gös- } \\
\text { terme fırsatı verdiği için katılırım. }\end{array}$ & 672 & & & & \\
\hline Kazanmanın mutluluğunu yaşamak için katılırım. & ,466 & & & & \\
\hline Yenilenme ve Rahatlama & & 3,86 & 9,38 & 2,23 & ,884 \\
\hline Ruhen yenilenmek için katılırım. & ,855 & & & & \\
\hline Bedenen yenilenmek için katılırım. & 840 & & & & \\
\hline Rahatlamak için katılırım. & ,814 & & & & \\
\hline Zihnimi rahatlatmak için katılırım. & ,734 & & & & \\
\hline Kaçış & & 3,30 & 8,74 & 1,48 & ,855 \\
\hline Baskılardan uzaklaşmak için katılırım. & 909 & & & & \\
\hline Kendimi meşgul etmek için katılırım. & ,906 & & & & \\
\hline Stresimi azalttığı için katılırım. & ,894 & & & & \\
\hline $\begin{array}{l}\text { Yapılması gereken işleri düşünmekten kurtulmak } \\
\text { için katılırım. }\end{array}$ & ,495 & & & & \\
\hline Keşfetme & & 3,71 & 5,56 & 1,27 & ,651 \\
\hline Açık alanlarda bulunmak için katılırım. & ,682 & & & & \\
\hline $\begin{array}{l}\text { Kendimi dinlemek (kafamı dinlemek) için katıll- } \\
\text { rım. }\end{array}$ & ,654 & & & & \\
\hline Yeni yerler keşfetmek için katılırım. & ,629 & & & & \\
\hline $\mathrm{KMO}=0,877 ;$ Bartlett Küresellik Testi $=9218,790$ & & & & & \\
\hline
\end{tabular}


Faktör analizinde her bir faktörün açıkladığı varyansın yüzdesi, faktörlerin önemini vurgulaması yönünden dikkat edilmesi gereken bir noktadır (Çemrek, Baykuş ve Özaydın, 2014, s. 73). Tablo 4'te de görüldüğü üzere varyansı en iyi açıklayan faktör birinci faktör, varyansı açıklama oranı en düşük olan faktör ise altıncı faktördür.

\subsection{Farklılıklara ilişkin Bulgular}

Çalışma kapsamında A ve B kişilik tiplerine sahip bireylerin, boş zaman aktivite tercihlerinin farkIılaşıp farklılaşmadığını anlamak için ki-kare testinden yararlanılmıştır. Ki-kare testi sonucuna göre yedi adet boş zaman aktivite türünden beşine katııımın kişilik tipine göre farklılaştığı görülmektedir. A ve $B$ kişilik tiplerine göre evde yapılan aktiviteler, sosyal içeriği yüksek olan aktiviteler, aktif olarak yapılan sportif aktiviteler, pasif olarak katılınan sportif aktiviteler ve açık alanda yapılan aktiviteler arasında anlamlı bir farklılık olduğu, Tablo 5'te görülmektedir. Öte yandan kültürel, eğitimsel ve sanatsal aktiviteler ve konaklama içeren turizm aktivitelerine katıımın kişilik tiplerine göre farklılaşmadığı sonucuna ulaşılmıştır. B tipi kişiliğe sahip bireylerin \%91'inin evde yapılan aktivitelere (203 kişi), \%86,1'inin sosyal içeriği yüksek olan aktivitelere (192 kişi) ve \%68,6'sının ise pasif olarak katılınan sportif aktivitelere (153 kişi) katılmayı tercih ettiği belirlenmiştir. Diğer tarafta, A tipi kişiliğe sahip bireylerin \%94,4'ünün aktif olarak yapılan sportif aktivitelerini (167 kişi), \%80,2'sinin ise açık alanda yapılan aktiviteleri (142 kişi) tercih ettikleri, Tablo 5 'ten anlaşılmaktadır.

Tablo 5. A ve B Kişilik Tiplerinin Boş Zaman Aktivite Tercihlerine Yönelik Farklılıklar

\begin{tabular}{|c|c|c|c|c|c|c|}
\hline \multirow{2}{*}{ Aktivite Türleri } & \multirow{2}{*}{$\begin{array}{l}\text { Katılım } \\
\text { Durumu }\end{array}$} & \multicolumn{2}{|c|}{ Kişilik Tipleri } & \multirow{2}{*}{ Toplam } & \multirow{2}{*}{$\begin{array}{l}\text { Yaklaşık } \\
\text { Ki-Kare } \\
\text { Değeri } \\
\left(x^{2}\right)\end{array}$} & \multirow{2}{*}{$\begin{array}{l}\text { Ki-Kare } \\
\text { Değeri } \\
\text { (Sig.) }\end{array}$} \\
\hline & & A Tipi & B Tipi & & & \\
\hline $\begin{array}{l}\text { Evde yapılan aktivi- } \\
\text { teler }\end{array}$ & $\begin{array}{l}\text { Evet } \\
\text { Hayır }\end{array}$ & $\begin{array}{l}21 \\
(11,9 \%) \\
156 \\
(88,1 \%)\end{array}$ & $\begin{array}{l}203 \\
(91,0 \%) \\
20 \\
(9,0 \%)\end{array}$ & $\begin{array}{l}400 \\
(100,0 \%)\end{array}$ & 250,995 & , 000 \\
\hline $\begin{array}{l}\text { Sosyal içeriği yük- } \\
\text { sek olan aktiviteler }\end{array}$ & $\begin{array}{l}\text { Evet } \\
\text { Hayır }\end{array}$ & $\begin{array}{l}42 \\
(23,7 \%) \\
135 \\
(76,3 \%)\end{array}$ & $\begin{array}{l}192 \\
(86,1 \%) \\
31 \\
(13,9 \%)\end{array}$ & $\begin{array}{l}400 \\
(100,0 \%)\end{array}$ & 158,111 & , 000 \\
\hline $\begin{array}{l}\text { Kültürel, eğitimsel } \\
\text { ve sanatsal aktivite- } \\
\text { ler }\end{array}$ & $\begin{array}{l}\text { Evet } \\
\text { Hayır }\end{array}$ & $\begin{array}{l}115 \\
(65,0 \%) \\
62 \\
(35,0 \%)\end{array}$ & $\begin{array}{l}128 \\
(57,4 \%) \\
95 \\
(42,6 \%)\end{array}$ & $\begin{array}{l}400 \\
(100,0 \%)\end{array}$ & 2,373 & , 075 \\
\hline $\begin{array}{l}\text { Sportif aktivitelere } \\
\text { aktif olarak katılım }\end{array}$ & $\begin{array}{l}\text { Evet } \\
\text { Hayır }\end{array}$ & $\begin{array}{l}167 \\
(94,4 \%) \\
10 \\
(5,6 \%)\end{array}$ & $\begin{array}{l}20 \\
(9,0 \%) \\
203 \\
(91,0 \%)\end{array}$ & $\begin{array}{l}400 \\
(100,0 \%)\end{array}$ & 288,966 & ,000 \\
\hline
\end{tabular}


Ceren AYDIN | Çağıl Hale ÖZEL

\begin{tabular}{|c|c|c|c|c|c|c|}
\hline $\begin{array}{l}\text { Sportif aktivitelere } \\
\text { seyirci olarak katı- } \\
\text { lım }\end{array}$ & $\begin{array}{l}\text { Evet } \\
\text { Hayır }\end{array}$ & $\begin{array}{l}59 \\
(33,3 \%) \\
118 \\
(66,7 \%)\end{array}$ & $\begin{array}{l}153 \\
(68,6 \%) \\
70 \\
(31,4 \%)\end{array}$ & $\begin{array}{l}400 \\
(100,0 \%)\end{array}$ & 49,297 & ,000 \\
\hline $\begin{array}{l}\text { Açık alan aktivite- } \\
\text { leri }\end{array}$ & $\begin{array}{l}\text { Evet } \\
\text { Hayır }\end{array}$ & $\begin{array}{l}142 \\
(80,2 \%) \\
35 \\
(19,8 \%)\end{array}$ & $\begin{array}{l}88 \\
(39,5 \%) \\
135 \\
(60,5 \%)\end{array}$ & $\begin{array}{l}400 \\
(100,0 \%)\end{array}$ & 67,099 & ,000 \\
\hline $\begin{array}{l}\text { Konaklama içeren } \\
\text { turizm hareketleri }\end{array}$ & $\begin{array}{l}\text { Evet } \\
\text { Hayır }\end{array}$ & $\begin{array}{l}134 \\
(75,7 \%) \\
43 \\
(24,3 \%)\end{array}$ & $\begin{array}{l}151 \\
(67,7 \%) \\
72 \\
(32,3 \%)\end{array}$ & $\begin{array}{l}400 \\
(100,0 \%)\end{array}$ & 3,078 & 079 \\
\hline
\end{tabular}

A ve $B$ kişilik tipleriyle, aktivite katıım amaçları arasında anlamlı bir fark olup olmadığını anlamak için ki-kare testine başvurulmuştur. Ki-kare testi sonucuna göre $A$ ve $B$ kişilik tipleri ile bu kişilik tiplerinin boş zaman aktivitelerine katılım amaçları arasında anlamlı bir farklıık olduğu tespit edilmiştir (yaklaşık ki-kare değeri $\left(x^{2}\right)$ : 196,053, sig: ,000 < 0,05). Katılımcıların kişilik tipleriyle boş zaman aktivitelerine katılımlarını etkileyen temel amaçlar, Tablo 6'da verilmiştir.

Aktivitelere katııırken sosyalleşmek ve rutinden kaçmak amacını belirten bireylerin büyük çoğunluğunun B tipi kişiliğe sahip olduğu tespit edilmiştir. B tipi kişilerin \%42,6'sı (95 kişi) sosyalleşmek amacıyla aktivitelere katıldığını belirtirken, \%41,7'si ise rutin hayattan kaçmak için boş zaman aktivitelerine katıldığını belirtmiştir. A tipi kişilerin ise boş zaman aktivitelerine, toplamda \%81,3 oranında kişisel gelişim sağlamak ve rekabet etmek amacıyla katıldığı Tablo 6 'dan anlaşılmaktadır.

Tablo 6. A ve B Kişilik Tiplerinin Boş Zaman Aktivitelerine Katılım Amaçlarındaki Farklııklar

\begin{tabular}{lllll}
\hline \hline Aktivitelere Katılım Amacı & \multicolumn{1}{c}{ Kişilik Tipi } & & & Ki-Kare Değeri \\
& $\begin{array}{l}\text { A Tipi } \\
(\% 44,2)\end{array}$ & $\begin{array}{l}\text { B Tipi } 223 \\
(\% 55,8)\end{array}$ & Toplam & (Sig.) \\
\hline Sosyalleşmek & $13(7,3 \%)$ & $95(42,6 \%)$ & $108(27,0 \%)$ & \\
Rutinden kaçmak & $18(10,2 \%)$ & $93(41,7 \%)$ & $111(27,8 \%)$ & \\
Kişisel gelişim sağlamak & $70(39,5 \%)$ & $27(12,1 \%)$ & $97(24,3 \%)$ &, 000 \\
Rekabet etmek & $74(41,8 \%)$ & $3(1,3 \%)$ & $77(19,3 \%)$ & \\
Diğer & $2(1,1 \%)$ & $5(2,2 \%)$ & $7(1,8 \%)$ & \\
Genel Toplam & & & $400(100,0 \%)$ & \\
\hline
\end{tabular}


Katılımcıların kişilik tipleri ile boş zaman aktivitelerine katılım güdülerinin oluşturduğu faktör grupları arasında anlamlı bir fark olup olmadığını anlamak için T-testine başvurulmuştur (Tablo 7).

Tablo 7. Boş Zaman Güdü Faktörlerinin A ve B Kişilik Tipine Göre Değişimi

\begin{tabular}{|c|c|c|c|c|c|c|}
\hline Faktör adı & $\begin{array}{l}\text { Kişilik } \\
\text { Tipi }\end{array}$ & Sıklık & $\begin{array}{l}\bar{X}(\text { Orta- } \\
\text { lama) }\end{array}$ & S.S. & t Değeri & p Değeri \\
\hline \multirow{2}{*}{ Sosyalleşme } & A Tipi & 223 & 3,65 & \multirow{2}{*}{1,12} & \multirow{2}{*}{,242 } & \multirow{2}{*}{809} \\
\hline & B Tipi & 177 & 3,70 & & & \\
\hline \multirow{2}{*}{ Kişisel Gelişim ve Başarma } & A Tipi & 223 & 3,52 & \multirow{2}{*}{1,10} & \multirow{2}{*}{,091 } & \multirow{2}{*}{,927 } \\
\hline & B Tipi & 177 & 3,46 & & & \\
\hline \multirow{2}{*}{ Rekabet } & A Tipi & 223 & 3,00 & \multirow{2}{*}{1,25} & \multirow{2}{*}{7,35} & \multirow{2}{*}{, $000^{*}$} \\
\hline & B Tipi & 177 & 2,36 & & & \\
\hline \multirow{2}{*}{ Yenilenme ve Rahatlama } & A Tipi & 223 & 3,81 & \multirow{2}{*}{0,98} & \multirow{2}{*}{,- 095} & \multirow{2}{*}{,924 } \\
\hline & B Tipi & 177 & 3,90 & & & \\
\hline \multirow{2}{*}{ Kaçış } & A Tipi & 223 & 3,33 & \multirow{2}{*}{1,20} & \multirow{2}{*}{,- 407} & \multirow{2}{*}{,684 } \\
\hline & В Tipi & 177 & 3,28 & & & \\
\hline \multirow{2}{*}{ Keşfetme } & A Tipi & 223 & 3,67 & \multirow{2}{*}{1,03} & \multirow{2}{*}{$-1,32$} & \multirow{2}{*}{, 186 } \\
\hline & B Tipi & 177 & 3,74 & & & \\
\hline
\end{tabular}

(Tüm ifadelerde varyanslar homojenlik göstermektedir.)

*A ve B tipi kişiliklerin boş zaman güdüleri arasında anlamlı bir farklıık mevcuttur.

Katılımcıların, kişilik tipleriyle sosyalleşme, kişisel gelişim ve başarma, yenilenme ve rahatlama faktörü, kaçış faktörü ve keşfetme faktörleri arasında anlamlı bir farklılık bulunamamıştır ( $p>0.05$ ). Bu durum, faktörlere ilişkin ifadelere verilen yanıtların ortalamalarının ve standart sapmalarının birbirine yakın olmasından da görülmektedir. Bu kapsamda, A ve B tipi kişileri boş zaman aktivitelerine yönelten güdülerin birbirine benzer güdüler olduğu söylenebilir. Ancak, rekabet faktörüne bakıldığında iki kişilik tipi arasındaki güdünün farklılaştığı görülmektedir. Bu bulgudan hareketle, A tipi kişiliğin $(\bar{x}=3,00)$ B tipi kişiliğe $(\bar{x}=2,36)$ göre daha fazla rekabet güdüsüyle boş zaman aktivitesine katıldığı söylenebilir. Alanyazına benzer şekilde A tipi kişilerin rekabet duygusunu yaşamak için boş zaman aktivitelerine katıldığı, bu çalışmada da ortaya çıkmıştır.

Çalışma kapsamında katılımcıların belirtmiş olduğu boş zaman aktivitelerine katılım amacı incelendiğinde B tipi kişilerin sosyalleşmek ve rutin hayattan kaçmak için boş zaman aktivitelerine katıdığı görülmektedir (Tablo 6). Ancak, t-testinin sonuçlarına göre A ve B tipi kişilerin boş zaman aktivitelerine katıım güdüleri incelendiğinde sosyalleşme ve kaçış faktöründe farklılaşmanın olmadığı görülmektedir. Bu durumdan yola çıkarak, B tipi kişilerin boş zaman aktivitelerine katılmadaki temel amaçları sosyalleşmek ve rutinden kaçmak olsa da bu bireyleri boş zaman aktivitelerine yönelten farklı güdülerin olduğu söylenebilir. Benzer şekilde A tipi kişilerin de "kişisel gelişimime katkı sağlamak için boş zaman aktivitelerine katılıım" şeklinde belirttikleri boş zaman aktivitelerine katılım amacı, "kişisel gelişim ve başarma" faktöründe farklılaşmamıştır. Bu durum da A tipi kişilerin kişisel 
Ceren AYDIN | Çağıl Hale ÖZEL

gelişim amacıyla bir aktiviteye katılmasının yanında "sosyalleşmek", "kaçış", "keşfetmek" ve "yenilenmek ve rahatlama" güdüleriyle de aktivitelere katıldığını göstermektedir. Bu durumu Koç (2007, s. 235), bireyin sahip olduğu bazı güdülerin farkında olmayabileceği, bazı durumlarda ise bireyin bilinçaltı tarafından güdülendiği şeklinde açıklamaktadır.

\section{Sonuç ve Tartışma}

Bu çalışma, Ayırıc Özellik Kuramı içinde ele alınan A ve B Kişilik Modeli ile bireylerin boş zaman davranışlarını kıyaslamayı amaçlamaktadır. Bu bağlamda A ve B kişilik tiplerinin hem tercih ettiği aktivitelerde hem de boş zaman aktivitelerine katılım güdülerinde farklılık olup olmadığı araştırılmıştır. Yapılan çalışmalar (Nickerson ve Ellis, 1991; Arai ve Hisamichi, 1998; Barnett, 2006; Kovacs, 2007; Jopp ve Hertzog, 2010) göstermektedir ki bireyin sahip olduğu kişilik özellikleri, bireyin tercih ettiği mal ve hizmet seçiminde olduğu gibi bireyin boş zamanlarında tercih ettiği aktivite seçimini de etkilemektedir. Boş zaman ürünleri sunan işletmeler arasında yoğun rekabetin yaşandığı günümüzde, bireyin istek ve gereksinimlerini karşılayabilmek ve kişiye özgü hizmet sunabilmek için bireyin sahip olduğu kişilik özelliklerinin göz önünde bulundurulması gerekmektedir. Bu bağlamda bireyin hangi kişilik özellikleriyle hangi güdüler doğrultunda boş zaman aktivitelerine yöneldiğinin bilinmesi, işletmeler açısından önem arz etmektedir.

Araştırmanın sonucunda bireyleri boş zaman aktivitelerine yönelten güdülerin altı boyutta toplandığı görülmektedir. Bu güdülenme boyutları; "Sosyalleşme" "Kişisel Gelişim ve Başarma" "Rekabet", "Yenilenme ve Rahatlama", "Kaçış" ve "Keşfetme"dir. Güdülenme ile ilgili kapsamlı bir alanyazın taramasından sonra 34 ifadeden 30'unun alanyazına benzer bir şekilde güdülenme boyutu oluşturduğu görülmüştür. Ancak, Keşfetme boyutu içinde yer alan "Açık alanlarda bulunmak için katıllrım" ifadesi ile "Yeni yerler keşfetmek için katıııım" ifadesi Dillard ve Bates'in (2011) çalışmasında "Kaçış" boyutunu oluşturmuştur. Benzer şekilde, bu iki ifade ile birlikte Keşfetme boyutunda yer alan "Kendimi dinlemek için katııırım" ifadesi Manfredo, Driver ve Tarrant'ın (1996) çalışmasında "Otonomi” boyutu içinde yer almıştır. Alanyazından farklı olarak bu çalışmada söz konusu üç ifade bir araya gelerek yeni bir boyut oluşturmuştur. Bahsi geçen güdülenme boyutu, araştırmacılar tarafından "Keşfetme" boyutu olarak adlandırımıştır. Örneklem grubu kapsamında değerlendirildiğinde Türk toplumunda "Açık alanlarda bulunmak için katıııı" ifadesi ile "Yeni yerler keşfetmek için katılıım" ifadesi, kaçış isteğini yansıtmamıştır. Keşfetme boyutu, bireyin hem kendini keşfetmesi hem de yeni yerler ve farklı mekânlar keşfetmek istemesi olarak değerlendirilebilir.

Friedman ve Rosenman (1974), A ve B tipi kişilerin özelliklerini tanımlarken B tipi kişinin, yarışmaktan çok eğlenmek için boş zaman aktivitelerine katıldığını belirtmiştir. Ancak bu çalışmada, $A$ ve $B$ tipi kişilerin eğlenme amacıyla boş zaman aktivitelerine katılmaları arasında anlamlı bir fark olmadığı ortaya çıkmıştır. Iso-Ahola ve Weissinger (1985) ve Tang (1986) yaptığı çalışmalarda, A tipi kişilerin boş zaman aktivitelerinde yarışmacı özelliğini ön plana çıkardı̆̆ını vurgulamıştır. Iso-Ahola ve Weissinger (1985) ve Tang'in (1986) çalışmalarına benzer şekilde, bu çalışmada A tipi kişiler boş zaman aktivitelerine diğer insanlarla yarışmak için katıldıklarını belirtmişlerdir. Çalışmadan elde edilen 
güdülenme boyutlarıyla kişilik tipleri arasında anlamlı bir fark olup olmadığına bakıldığında "Rekabet" boyutunun kişilik tipine göre farklılaştığı görülmektedir. Yapılan çalışmalara (Friedman ve Rosenman, 1974; Iso-Ahola ve Weissinger, 1985; Tang, 1986) benzer olarak A tipi kişilik özelliğine sahip bireylerin boş zaman aktivitelerine katıırken rekabet özelliğini öne çıkarmak istedikleri sonucuna varılmıştır.

Iso-Ahola ve Weissinger'in (1985) çalışmasında belirtilen A tipi kişilerin B tipi kişilere göre açık alanda yapılan aktiviteleri daha çok tercih etmesi sonucuyla bu araştırmadan elde edilen sonucun örtüştüğü görülmektedir. Tang (1986), A tipi kişilerin boş zamanlarında dinlenmekten çok hareket etmekten hoşlandığını belirtmiştir. Benzer olarak, bu çalışmadan elde edilen verilere göre A tipi kişilerin evde yapılan aktivitelerden çok sportif uğraşlarda aktif olunan aktivitelere katıldıkları ortaya çıkarılmışır.

B tipi kişilik özelliğine sahip bireylerin çok azı boş zaman aktivitelerine katılım amacının kişisel gelişim sağlamak olduğunu belirtmiştir. Ancak, boş zaman aktivite seçimlerinde "Kültürel, Eğitimsel ve Sanatsal Aktiviteler" de A ve B tipi kişiliklerde belirgin farklar görülmemiş ve her iki kişilik tipinin de bu aktivitelere büyük oranda katıldığı belirlenmiştir. Bu noktada çalışmanın sonucu, Jenkins (1975) tarafından yapılan çalışmanın sonucundan ayrılmaktadır. Jenkins (1975), B tipi bireylerin A tipi bireylerden daha çok kültürel aktiviteleri tercih ettiğini belirtmiş̧ir. Ayrıca, "Kişisel Gelişim ve Başarma" boyutunda da kişilik tipleri arasında anlamlı bir fark bulunmamıştır.

\section{8. Öneriler}

B tipi kişilik özelliğine sahip bireylerin yarısından fazlasının sosyal aktiviteleri tercih ettiği görülmektedir. Ayrıca, B tipi kişilerin büyük bir bölümü sosyal ilişkilerini kuvvetlendirmek amacıyla boş zaman aktivitelerine katıldıklarını belirtmişlerdir. Bu bulgulara ek olarak B tipi kişilik özelliğine sahip olan diğer büyük bir grup ise evde yapılan aktiviteleri tercih etmektedir. Bu sonuçtan hareketle sosyal içeriği yüksek olan aktiviteler sunan işletmeler, büyük bir potansiyel oluşturan ev aktivitelerini tercih eden grubu evden dışarı çıkarabilmek için sosyal ilişkileri kuvvetlendirme yönünü ön plana çıkaran reklam ve pazarlama faaliyetleri yürütebilir.

Rutinden kaçmak amacıyla boş zaman aktivitelerine katıldığını belirten B tipi bireyler, sürekli katıldıkları aktivitelerin de belirli bir süre sonra rutinleşmesini istemeyecektir. B tipi bireyler, boş zamanlarında evde yapılan aktiviteleri, sosyal içeriği yüksek olan aktiviteleri ve sportif aktivitelere seyirci olarak katılınan aktiviteleri tercih ettiğini belirtmiştir. B tipi bireylerin, bu aktivitelere daha fazla katılmalarının sağlanabilmesi için söz konusu üç aktivite türüne yönelik hizmet sunan işletmelerin devamlı olarak kendilerini yenilemeleri gerekmektedir. Örneğin; sosyal içeriği yüksek olan aktiviteler içinde yer alan kafelerin; menüde, fiziksel kanıtlarda ya da mekânın atmosferinde yaptıkları bir değişiklik, müşteri grubu içinde yer alan B tipi bireylerin kendilerini tercih etmelerini sağlayabilir. Diğer yandan, evde yapılan aktiviteler için ürün üreten işletmeler, ürettikleri her yeni ürünle B tipi bireylerin evde yapılan aktivitelere daha fazla katılmasını sağlayabilir. Örneğin; yeni çıkan bir oyun konsolu, çıkış tarihinden bir müddet sonra ek donanımlar (Xbox Kinect, PS Move, PS VR) geliştirerek evde oyun oynama deneyimini farklılaştırabilmektedir. Bir başka örnek ise dijital tabanlı film servisi veren 


\section{Ceren AYDIN | Çağıl Hale ÖZEL}

firmalardır. Bu firmalar da tüketicilerine farkı bir deneyim yaşatmak için boyutları çok büyük olmasına rağmen, üç boyutlu filmleri dijital tabanlarına eklemiştir. Benzer bir biçimde, hobi bahçe ürünleri ve hobi mutfak malzemeleri sunan işletmeler, kendilerini yenilediği sürece evde yapılan aktivitelere katılan B tipi bireyler tarafından sıklıkla tercih edilebilecektir. B tipi bireylerin katılmayı tercih ettiği bir diğer aktivite, sportif aktivitelere seyirci olarak katılımdır. Futbol, basketbol ve voleybol gibi spor dallarının maçlarında devre aralarında yapılan dans ve smaç gösterileri, çekilişler, B tipi bireylerin bu aktivitelere daha fazla katılmasını sağlayabilir.

Güdülenme boyutları ile kişilik tipleri arasındaki farklılıklara ilişkin bulgularda A ve B tipi kişilik özelliğine sahip bireyler arasında 'Sosyalleşme" "Kaçış" "Keşfetme" "Kişisel Gelişim ve Başarma" "Yenilenme ve Rahatlama" güdüleri arasında anlamlı bir fark bulunamamıştır. Ancak, soru formundaki boş zaman aktivitelerine katılmanın temel amacına ilişkin soruya verilen yanıtlarla güdüler ile ilgili bölüme verilen yanıtlar arasında belirgin farklar mevcuttur. Nitekim B tipi bireylerin yarısına yakın bir kısmı, boş zaman aktivitelerine katılım amacının, A tipi bireylerden farklı olarak sosyalleşmek olduğunu belirtmişlerdir. Ancak, bu fark, boş zaman aktivitelerine katılım güdülerine ilişkin bölümde ortaya çıkmamıştır. Bu sonuçtan yola çıkarak, A tipi kişilik özelliğine sahip bireylerin boş zaman aktivitelerine katılmadaki temel amacının rekabet etmek olduğu, diğer yandan bu bireylerin farkında olmadan farklı güdülerle de boş zaman aktivitelerine katıldıkları söylenebilir. A tipi kişilik özelliğine sahip bireylerin bir kısmının sosyal içeriği yüksek olan aktiviteleri tercih etmesinin altında yatan neden, bu bireylerin farkında olmadan sosyalleşmek istemeleri olabilir. Bu bulgulardan hareketle, kafeler gibi sosyal içeriği yüksek aktiviteler sunan işletmeler, A tipi bireyleri çekebilmek adına rekabet unsuru içeren yarışmalar, oyunlar düzenleyebilir ve sosyalleşmeyi ön plana çıkaracak tanıtımlar yapabilir.

Gelecekte kişilik özellikleri ile boş zaman aktivitelerine katıım arasındaki ilişkiyi ele alacak çalışmalarda, bireyi boş zaman aktivitelerine yönelten güdüler, iki farklı kültür yapısına sahip toplumun karşılaştırıması şeklinde ele alınabilir. Böylece, kişilik özelliklerine göre farklılık gösteren boş zaman davranışlarının, kültürlere göre farklılaşıp farklılaşmadığı belirlenebilir. Yine boş zaman aktiviteleri içinde yer alan özel ilgi gruplarına (dağcılık kulübü, bisiklet kulübü, dalgıçıı, balık tutma gibi) üye olan bireyler üzerine çalışmalar yapılarak hangi aktivite grubunun hangi kişilik özelliğine sahip olan bireylerden oluştuğu karşılaştırmalı olarak ele alınabilir.

\section{Kaynaklar}

Aktaş, A. M. (2001). Bir Kamu Kuruluşunun Üst Düzey Yöneticilerinin İ̧̧ Stresi ve Kişilik Özellikleri. Ankara Üniversitesi SBF Dergisi, 56(4), 25-43.

Alpar, R. (2014). Uygulamalı İstatistik ve Geçerlik-Güvenilirlik. (3. Baskı). Ankara: Detay Yayınclık.

Altunışık, R., Coşkun, R., Bayraktaroğlu, S. ve Yıldıım, E. (2007). Sosyal Bilimlerde Araştırma Yöntemleri: SPSS Uygulamalı. Sakarya: Sakarya Yayınclık. 
Arai, Y. ve Hisamichi, S. (1998). Self-Reported Exercise Frequency and Personality: A PopulationBased Study in Japan. Perceptual and Motor Skills, 87(3f), 1371-1375.

Barnett, L. A. (2006). Accounting for Leisure Preferences from within: The Relative Contributions of Gender, Race or Ethnicity, Personality, Affective Style, and Motivational Orientation. Journal of Leisure Research, 38(4), 445.

Baud-Bovy, M. ve Lawson, F. (1998). Tourism and Recreation: Handbook of Planning and Design. Architectural Press.

Becker, M. A. ve Byrne, D. (1984). Type A Behavior and Daily Activities of Young Married Couples. Journal of Applied Social Psychology, 14(1), 82-88.

Burger, J. M. (2006). Kişilik-Psikoloji Biliminin İnsan Doğasına Dair Söyledikleri. İstanbul: Kaknüs Yayınları.

Burke, R. J. ve Deszca, E. (1984). What Makes Sammy Run-So Fast and Aggressively? Beliefs and Fears Underlying Type A Behaviour. Journal of Organizational Behavior, 5(3), 219-227.

Çemrek, F., Baykuş, H. ve Özaydın, Ö. (2014). Sosyal Medya Kullanım ve Davranışlarının Kullanımlar ve Doyumlar Yaklaşımı Bağlamında İncelenmesi: Eskişehir Osmangazi Üniversitesi Örneği. Alphanumeric Journal, 2(2), 61-76.

Dillard, J. E. ve Bates, D. L. (2011). Leisure Motivation Revisited: Why People Recreate. Managing Leisure, 16(4), 253-268.

Durmuş, B., Yurtkoru, E. S. ve Çinko, M. (2011). Sosyal Bilimlerde SPSS'le Veri Analizi. İstanbul: Beta Yayıncilık.

Eysenck, H. J. ve Wilson, G. D. (1995). Kişiliğinizi Tanıyın. İstanbul: Remzi Kitapevi.

Friedman, M. ve Rosenman, R. H. (1974). Type A Behavior and Your Heart. NY: Fawcett Books.

George, D. ve Mallery, M. (2003). Using SPSS for Windows Step by Step: A Simple Guide and Reference. Boston, MA: Allyn And Bacon.

Harden, D. M. (2008). The Five Factor Model of Personality and Leisure Experience (Basılmamış Doktora Tezi). California: California State University.

İnanç, B. Y. ve Yerlikaya, E. (2010). Kişilik Kuramları. Ankara: Pegem Akademi.

Iso-Ahola, S. E. ve Weissinger, E. (1985). Relationship Between Type A Coronaryprone Behavior and Leisure Patterns. In NRPA Leisure Reassure Symposium, USA: Dallas.

Jenkins, C. D. (1975). The Coronary-Prone Personality. İçinde W. D. Gentry and R. E. Williams (Editör), Psychological Aspects of Myocardial Infarction and Coronary Care (5-23). St. Louis: C. V. Mosby Co. 
Ceren AYDIN | Çağıl Hale ÖZEL

Jopp, D. S. ve Hertzog, C. (2010). Assessing Adult Leisure Activities: An Extension of a Self-Report Activity Questionnaire. Psychological Assessment, 22(1), 108-120.

Kalaycı, Ş. (2014). SPSS Uygulamalı Çok Değişkenli İstatistik Teknikler. Ankara: Asil Yayın Dağıtım.

Karaküçük, S. ve Gürbüz, B. (2007). Rekreasyon ve Kent (li) leşme. Ankara: Gazi Kitabevi.

Koç, E. (2007). Tüketici Davranışı ve Pazarlama Stratejileri: Global ve Yerel Yaklaşım. Ankara: Seçkin Yayıncilık.

Kozak, M. (2014). Bilimsel Araştırma: Tasarım, Yazım ve Yayım Teknikleri. Ankara: Detay Yayıncılık.

Kovacs, A. (2007). The Leisure Personality: Relationships Between Personality, Leisure Satisfaction, and Life Satisfaction, School of Health, Physical Education and Recreation. (Basılmamış Doktora Tezi). Indiana: Indiana University.

Larsen, R. J., Diener, E. D. ve Emmons, R. A. (1985). An Evaluation of Subjective Well-Being Measures. Social Indicators Research, 17(1), 1-17.

Mannell, R. C. ve Kleiber, D. A. (1997). A Social Psychology of Leisure. PA: Venture Publishing Inc.

Manfredo, M. J., Driver, B. L. ve Tarrant, M. A. (1996). Measuring Leisure Motivation: A MetaAnalysis of the Recreation Experience Preference Scales. Journal of Leisure Research, 28(3), 188.

McCrae, R. R. ve Costa, P. T. (2003). Personality in Adulthood: A Five-Factor Theory Perspective. NY: Guilford Press.

Morris, T. ve Rogers, H. (2004). Measuring Motives for Physical Activity. In Sport and Chance of Life: Proceedings Oo 2004 International Sport Science Congress (pp. 242- 250). Seoul, Korea: KAHPERD.

Myers, B. I. ve Myers, P. B. (1980). Gifts Differing: Understanding Personality Type. Mountain View, CA: Davies-Black Publishing.

Nardi, Peter M. (2006). Doing Survey Research: A Guide to Quantitative Methods. İkinci Basım. Boston: Pearson/Allyn and Bacon.

Nickerson, N. P. ve Ellis, G. D. (1991). Traveler Types and Activation Theory: A Comparison of Two Models. Journal of Travel Research, 29(3), 26-31.

Pelletier, L.G., Vallerand, R.J., Brière, N.M. ve Blais, MR. (1989). Construction Et Validation De I'Échelle De Motivation Vis-À-Vis Les Loisirs (EML). Communication Présentée Au Congrès Annuel De La SQRP, Ottawa, ON, 28 Octobre. Résumé Des Communications.

Plog, S. (2001). Why Destination Areas Rise and Fall in Popularity: An Update of a Cornell Quarterly Classic. The Cornell Hotel and Restaurant Administration Quarterly, 42(3), 13-24. 
Powers, D. A. ve Xie, Y. (2000). Statistical Methods for Categorical Data Analysis. Diego, California: Academic Press.

Rogers, H. Ve Morris, T. (2003). An Overview of the Development and Validation of the Recreational Exercise Motivation Measure (REMM). In XI the European Congress of Sport PsychologyProceedings. Copenhagen, Denmark: University of Copenhagen.

Saruhan, Ş. C. ve Özdemirci, A. (2011). Bilim, Felsefe ve Metodoloji. İstanbul: Beta Yayıncılık.

Sekaran, U. (1992). Research Methods for Business: A Skill Building Approach, USA: John Wiley and Sons Inc.

Tang, T. L. P. (1986). Effects of Type A Personality and Task Labels (Work vs. Leisure) on Task Preference. Journal of Leisure Research, 18(1), 1-11.

Tang, T. L. P. (1988). Effects of Type a Personality and Leisure Ethic on Chinese College Students' Leisure Activities and Academic Performance. The Journal of Social Psychology, 128(2), 153164.

İnternet Kaynakları

Türkiye İstatistik Kurumu (2014). www.tuik.gov.tr/ , E.T.: 01.05.2015. 